\title{
The Photoassimilation of Organic Compounds by Autotrophic Blue-green Algae
}

\author{
By D. S. HOARE, S. L. HOARE AND R. B. MOORE \\ Department of Microbiology, The University of Texas, Austin, Texas
}

(Accepted for publication 26 May 1967)

\begin{abstract}
SUMMAR Y
Four obligately photoautotrophic blue-green algae were shown to assimilate acetate. This reaction was light dependent and was greatly decreased in the absence of carbon dioxide. Acetate was incorporated mainly into the ethanol extractable (lipid) fraction of the organisms and into the protein fraction. Only four amino acids (glutamate, proline, arginine, leucine) were significantly radioactive as a result of the incorporation of (I-) or $(2-)^{14} \mathrm{C}$ acetate. Partial degradations of amino acids derived from specifically labelled acetate and enzyme assays on crude cell-free extracts of Anacystis nidulans support the operation of established pathways for the biosynthesis of these amino acids. Growth of blue-green algae was not significantly affected by the presence of moderate concentrations of the sodium salts of the lower fatty acids, with the exception of propionate, low concentrations of which inhibited growth.
\end{abstract}

The blue-green algae are a ubiquitous group of procaryotic micro-organisms which grow photosynthetically and, unlike the photosynthetic bacteria, produce oxygen. Apart from studies on their photosynthetic activities and, with certain species, also on their nitrogen-fixing activities, surprisingly few biochemical investigations have been made on this important group of organisms. Although blue-green algae commonly occur in soil and waters containing organic matter, very few studies have been made on their ability to metabolize organic compounds. It is believed that most of the blue-green algae are obligate photoautotrophs. This seems well established for three pure cultures of blue-green algae studied by Kratz \& Myers (1955a, b): namely Anacystis nidulans, Anabaena variabilis and Nostoc muscorum G. These organisms should therefore be useful for a study of the phenomenon of obligate photoautotrophy. It has been found that some obligately autotrophic photosynthetic bacteria can assimilate certain organic compounds (Sadler \& Stanier, I960; Hoare \& Gibson, I964). Accordingly a study has been made of the ability of some blue-green algae to assimilate some simple organic compounds. A preliminary account of part of these investigations has been published (Hoare \& Moore, 1965; Hoare, Hoare \& Moore, I $966 a, b)$.

\section{METHODS}

Abbreviations used. ATP: adenosine triphosphate; CoA: coenzyme A; DCMU: 3-(3,4-dichlorophenyl)-I, I, dimethyl urea; NAD: nicotinamide adenine dinucleotide; NADP: nicotinamide adenine dinucleotide phosphate.

Organisms. Strains of Anacystis nidulans, Anabaena variabilis and Nostoc muscorum G were obtained from Dr J. Myers (Zoology Department of The University of Texas).

Vol. 49, No. 2, was issued 20 December 1967 
Anabaena flos-aquae A-37 was kindly provided by Dr R. G. Tischer (Mississippi State University). Cultures were maintained under constant illumination at $25-30^{\circ}$ on agar slopes containing medium DM (see below) supplemented with ammonium chloride (O. I g.).

Growth of organisms. Organisms were grown photosynthetically on the medium (DM) of van Baalen (1965a), which is a modification of the medium ' $\mathrm{D}$ ' used by Kratz \& Myers (I955a); after equilibration with air $+\mathrm{I}-2 \%(\mathrm{v} / \mathrm{v})$ carbon dioxide the medium was at $\mathrm{pH} 7 \cdot 6-7 \cdot 8$. For growth experiments $20 \mathrm{ml}$. medium in $22 \times 175 \mathrm{~mm}$. glass tubes were cotton-wool plugged and gassed continuously with a mixture of $\mathrm{I}-2 \%(\mathrm{~V} / \mathrm{v}) \mathrm{CO}_{2}$ in air; the tubes were immersed in a water bath and were illuminated by a bank of fluorescent lights providing a light intensity of $1000 \mathrm{ft}$. candles and maintaining the cultures at $30^{\circ}$. Growth was determined by following extinction at $600 \mathrm{~m} \mu$ in a Bausch \& Lomb ('Spectronic-20') spectrophotometer. For larger scale growth, cultures were grown in the same medium in 2-1 cylinders by using $10 \mathrm{ml}$. inoculum to $1500 \mathrm{ml}$. medium. Cultures were harvested after incubation for $40 \mathrm{hr}$ in the light. In some cases cultures were grown in the continuous culture apparatus of Myers \& Clark (1944), operated manually.

For photoassimilation experiments organisms were harvested under aseptic conditions by transferring cultures to sterile polyethylene bottles which were centrifuged for I $5 \mathrm{~min}$ at $10,000 \mathrm{~g}$ at $20^{\circ}$, and washed three times in sterile medium DM. For enzyme experiments aseptic conditions were not necessary. After centrifugation and washing, the organisms were stored as a packed mass at $-10^{\circ}$.

Determination of viable counts. The procedure was a slight modification of that used by van Baalen (1965a). Samples from cultures were harvested and the organisms washed three times and appropriately diluted in the same growth medium. Final dilutions were plated in $0.05 \mathrm{ml}$. of medium $\mathrm{DM}+\mathrm{I} \%$ agar on the surface of DM agar plates so that quadruplicates of three different dilutions could be placed on a single plate. The plates were inverted in a dessicator containing a small amount of water, gassed three times with $99 \%(\mathrm{v} / \mathrm{v}) \mathrm{N}_{2}+\mathrm{I} \%$ (v/v) $\mathrm{CO}_{2}$ and sealed. The system was illuminated by two $150 \mathrm{~W}$. tungsten lamps and was maintained at about $35^{\circ}$ with a fan. After 2-4 days of incubation colony counts were made under a binocular dissecting microscope. A standard curve relating number of viable organisms $/ \mathrm{ml}$. and extinction at $600 \mathrm{~m} \mu$ with incubation time was determined.

Photoassimilation experiments. The photoassimilation of radioactive organic compounds was determined in the following manner. Organisms harvested and washed under sterile conditions were suspended in sterile growth medium to the appropriate concentrations and $20 \mathrm{ml}$. amounts were transferred aseptically to sterile glass tubes $22 \times 175 \mathrm{~mm}$. fitted with cotton-wool plugs and gassing tubes as in the growth studies. Reagent-grade organic acids ( $\mathrm{Na}$ salts) were added and the tubes were gassed with $2 \%(\mathrm{v} / \mathrm{v}) \mathrm{CO}_{2}$ in air, illuminated at $30^{\circ}$ and equilibrated for $30 \mathrm{~min}$. Sterile radioactive organic substrates $(2 \mu \mathrm{C}$ ) were then added. Samples (I ml.) were removed aseptically at intervals, filtered through $450 \mathrm{~m} \mu$ pore-diameter Millipore filters and washed with $20 \mathrm{ml}$. $0.01 \mathrm{M}$-carrier organic substrates. The filters were mounted on aluminium planchettes with adhesive, dried and assayed for radioactivity with a Nuclear Chicago thin-window proportional flow counter.

Enzyme assays. Preparation of cell-free extracts. Most enzyme assays were done with crude (undialyzed) cell-free extracts made as follows. Stored packed organisms 
2-3 g. wet weight were mixed with Io g. washed No. IoA Ballotini glass beads and suspended in $15 \mathrm{ml} .0 .05 \mathrm{M}$-potassium phosphate buffer $(\mathrm{pH} 7.0$ ). The suspension was chilled on ice and treated with ultrasonics for $90 \mathrm{sec}$. with an M.S.E. sonic disintegrator with a $\frac{1}{2}$ in. diameter probe. The suspension was then centrifuged for $15 \mathrm{~min}$. at $16,000 \mathrm{rev} . / \mathrm{min}$. in a Sorvall refrigerated centrifuge at $+2^{\circ}$ and the supernatant fluid centrifuged for $30 \mathrm{~min}$. at $100,000 \mathrm{~g}$ in a Spinco Model $\mathrm{L}$ ultracentrifuge. The resulting clear blue extract was used for enzyme assays.

Protein estimations were done by determination of the extinction at 260 and $280 \mathrm{~m} \mu$ (Warburg \& Christian, 1942).

Specific enzyme assays were done as follows.

Acetic thiokinase (acetyl coenzyme A synthetase) was assayed by the procedure of Jones \& Lipmann (I955). Reaction mixtures of $\mathrm{I} \cdot 5 \mathrm{ml}$. total volume contained ( $\mu$ moles): 0.08 coenzyme A, Io ATP, $20 \mathrm{~K}$ acetate, I00 $\mathrm{K}$ phosphate (pH 7.5), Io $\mathrm{MgCl}_{2}$, Io glutathione and Io (neutralized) hydroxylamine. The reaction proceeded faster in the absence of potassium fluoride. Extracts containing 2-6 mg. protein were incubated with the above components for $30 \mathrm{~min}$. at $35^{\circ}$. The reaction was stopped by adding $\mathrm{I} \cdot 5 \mathrm{ml}$. ferric chloride reagent containing $\mathrm{IO} \%(\mathrm{w} / \mathrm{v}) \mathrm{FeCl}_{3} .6 \mathrm{H}_{2} \mathrm{O}$ and $3.3 \%(\mathrm{w} / \mathrm{v})$ trichloroacetic acid in $0.66 \mathrm{~N}-\mathrm{HCl}$ (Lipmann \& Tuttle, 1945). Tubes were centrifuged and the extinction of the supernatant fluid measured at $540 \mathrm{~m} \mu$ against a ferric chloride reagent blank.

Citrate synthase was assayed by determining citrate formation from oxaloacetate and acetyl coenzyme A. Reaction mixtures ( $5 \mathrm{ml}$.) contained ( $\mu$ moles): Ioo potassium oxaloacetate (freshly neutralized to $\mathrm{pH} 7 \cdot 0$ ); 8 acetylcoenzyme $\mathrm{A} ; 50$ cysteine; $100 \mathrm{~K}$ phosphate ( $\left.\mathrm{pH}^{7} \cdot 5\right)$; extract. Control tubes were without oxaloacetate. Tubes were incubated at $35^{\circ}$ and samples $(0.5 \mathrm{ml}$.) were withdrawn at different times for determination of residual acetylcoenzyme A and of citrate. Acetylcoenzyme A was determined by the hydroxamate procedure of Lipmann \& Tuttle (1945). Citrate was determined by the colorimetric procedure of Taylor (1953). Acetylcoenzyme A was prepared by the acetylation of coenzyme A with acetic anhydride (Stadtman, 1957).

Citrate synthase was also demonstrated by coupling the acetic thiokinase system (in the absence of hydroxylamine) with oxaloacetate and determining the citrate formed. Formation of citrate from radioactive acetate was also determined in this way (details in the results section).

Isocitric-NADP dehydrogenase. This was assayed spectrophotometrically by following the reduction of NADP at $340 \mathrm{~m} \mu$. Reaction mixtures of $3 \mathrm{ml}$. total volume contained ( $\mu$ moles): 0.5 potassium DL-isocitrate, $0.5 \mathrm{NADP}$; Io $\mathrm{MgCl}_{2}$; $100 \mathrm{KH}_{2} \mathrm{PO}_{4}$ buffer $(\mathrm{pH} 7 \cdot 0)$; extract. Control mixtures without isocitrate were used. Rates of NADP reduction were determined against a blank containing extract + buffer only. The stoichiometry of the reaction was determined by estimating the $\alpha$-ketoglutarate formed as the 2,4-dinitrophenylhydrazone by the procedure of Friedmann (1957).

Transaminases. Transamination was demonstrated qualitatively. Reaction mixtures of I ml. total volume contained ( $\mu$ moles): $25 \mathrm{~L}$-amino acid; 50 potassium $\alpha$-ketoglutarate; extract in $0.05 \mathrm{M}-\mathrm{KH}_{2} \mathrm{PO}_{4}(\mathrm{pH} 7 \cdot 0)$. Control tubes were included in which $\alpha$-ketoglutarate and the different amino acids were incubated alone with the extract. Tubes were incubated $60 \mathrm{~min}$. at $35^{\circ}$ and were then deproteinized by treatment with $0 . \mathrm{I} \mathrm{ml}$. glacial acetic acid $+0.5 \mathrm{ml} .95 \%(\mathrm{v} / \mathrm{v})$ ethanol in water. Protein-free supernatant fluids were subjected to paper electrophoresis on Whatman 3 MM paper in a 
pyridine + acetic acid buffer $(\mathrm{pH} 3 \cdot 6)$ for $2 \mathrm{hr}$ at 2000 V. (Dixon, Kauffman \& Neurath, 1958) together with glutamate markers. Strips were dried and then dipped in ninhydrin $(0 \cdot 1 \%, w / v$, in acetone) to detect glutamate.

Glutamic dehydrogenase was tested in reaction mixtures of $3 \mathrm{ml}$. final volume containing ( $\mu$ moles): 50 potassium L-glutamate; $5 \mathrm{NAD}$ or NADP; $100 \mathrm{KH}_{2} \mathrm{PO}_{4}$ (pH $7 \cdot 0$ ); extract. The reaction was also tested in the direction of glutamate synthesis as described in the Results section.

$\mathrm{N}$-Acetyl glutamate kinase. Reaction mixtures of $\mathrm{I} \cdot 5 \mathrm{ml}$. final volume contained ( $\mu$ moles): $20 \mathrm{~N}$-acetyl-L-glutamate; Io ATP; $10 \mathrm{MgCl}_{2} ; 200$ (neutralized) hydroxylamine; extract. Tubes were incubated at $35^{\circ}$ and were deproteinized with the ferric chloride reagent of Lipmann \& Tuttle (1945) and extinction of the ferric complex measured at $540 \mathrm{~m} \mu$ as in the assay for acetic thiokinase.

$\alpha-N$-Acetylornithine $\delta$-transaminase was assayed by the procedure of Albrecht \& Vogel (1964). Reaction mixtures of I ml. total volume contained ( $\mu$ moles): roo $\mathrm{KH}_{2} \mathrm{PO}_{4}(\mathrm{pH} 8 \cdot 0), 5 \alpha-N$-acetyl-L-ornithine; Io $\alpha$-ketoglutarate; 0.05 pyridoxal phosphate; extract. Controls were set up in which $\alpha-N$-acetylornithine was omitted, and in which it was added at the end of the incubation period. Reactions were stopped by adding $0.3 \mathrm{ml} .6 \mathrm{~N}-\mathrm{HCl}$ and the tubes heated $30 \mathrm{~min}$. at $100^{\circ}$, cooled, I ml. of $3.6 \mathrm{M}-\mathrm{Na}$ acetate $+0.2 \mathrm{ml} .0 .033 \mathrm{M}-\sigma$-aminobenzaldehyde added and the extinction at $440 \mathrm{~m} \mu$ measured after $15 \mathrm{~min}$.

$N$-acetylglutamate-ornithine transacetylase. This enzyme was demonstrated qualitatively (details in the Results section).

Ornithine transcarbamylase. This was assayed by the procedure of Spector \& Lipmann (I955). Reaction mixtures of I ml. total volume contained ( $\mu$ moles): I50 tris $(\mathrm{pH} 8 \cdot 0) ; 5 \mathrm{MgCl}_{2} ; 8$ L-ornithine; 6 dilithium carbamyl phosphate; cell-free extract. Tubes were incubated for different times at $35^{\circ}$ and the reaction stopped by adding $5 \mathrm{ml}$. $0.5 \mathrm{M}$-perchloric acid. Tubes were centrifuged and appropriate samples of the clear supernatant fluids were taken for citrulline estimation by the colorimetric procedure of Archibald (1944) as modified by Oginsky (1957).

\section{RESULTS}

Effect of organic compounds on growth of Anacystis nidulans. Preliminary experiments were done to examine the effect of sodium acetate on the rate of growth of Anacystis nidulans. A series of tubes containing $20 \mathrm{ml}$. medium DM supplemented with different concentrations of sodium acetate were inoculated with $0.1 \mathrm{ml}$. of a suspension of washed organisms adjusted to an extinction of $\mathrm{I} \cdot 0$ at $600 \mathrm{~m} \mu$, corresponding to $5 \times 10^{6}$ organisms $/ \mathrm{ml}$. Growth was followed by measuring the extinction at $600 \mathrm{~m} \mu$ as a function of time. Typical growth curves are illustrated in Fig. I. Acetate never stimulated growth, but concentrations of 0.0I-0.04 M inhibited growth. Determination of viable counts showed that even at the higher growth inhibitory concentrations of acetate, the cultures were still viable after a I2-hr incubation period.

Similar growth experiments were done with other fatty acids. In each case highly purified substances were used as the sodium salts prepared by neutralization of freshly distilled fatty acids. The lower straight chain and branched saturated fatty acids were tested over the range $0.00 \mathrm{I}-0.02 \mathrm{M}$. In most cases the results were very similar to those with acetate: namely growth was significantly inhibited only by relatively high concen- 
trations of fatty acid. However, propionate was a very much more potent growth inhibitor, with significant growth inhibition at $\mathrm{IO}^{-4} \mathrm{M}$. and complete inhibition of growth by $5 \times 10^{-4} \mathrm{M}$. Determinations of viable counts indicated that still higher concentrations of propionate killed the organisms. Low concentrations of propionate also inhibited growth of Anabaena variabilis and Nostoc muscorum G.

Several compounds were tested to determine whether the growth inhibition by propionate could be annulled. Acetate specifically annulled the growth inhibitory effects of propionate for Anacystis nidulans, Anabaena variabilis and Nostoc muscorum G. Other compounds tested over a range of concentrations $\left(\mathrm{IO}^{-2}\right.$ to $\left.\mathrm{IO}^{-5} \mathrm{M}\right)$ including butyrate, pyruvate, $\beta$-alanine, pantothenic acid, yeast extract $(0.005-0.5 \%$, w/v) and casamino acids $(0.005-0.5 \%, \mathrm{w} / \mathrm{v})$ did not annul the growth inhibitory action of propionate. Typical results are given in Table I. Attempts to obtain reproducible growth rates with different concentrations of acetate and propionate intended to determine whether propionate might compete with acetate, were not successful. Qualitatively, growth inhibition by propionate of all three blue-green algae was consistently annulled by acetate.

\section{Table I. Effect of acetate and propionate on growth of blue-green algae}

Organisms were grown at $30^{\circ}$ in the light in $20 \mathrm{ml}$. medium DM with Na acetate and/or $\mathrm{Na}$ propionate at the final concentrations indicated; cultures gassed continuously with $2 \%(\mathrm{v} / \mathrm{v}) \mathrm{CO}_{2}$ in air. Extinction at $600 \mathrm{~m} \mu$ measured at intervals and growth rate constants $(\mathrm{K})$ in $\log _{10}$ units per day determined according to Kratz \& Myers (I955a).

\begin{tabular}{lccc} 
& \multicolumn{3}{c}{ Concn of } \\
Acetate & $\begin{array}{c}\text { Propionate } \\
(\mathrm{M})\end{array}$ & $\mathrm{K}$ \\
Anacystis nidulans & 0 & 0 & $0.9 \mathrm{I}$ \\
& 0 & $0.00 \mathrm{I}$ & 0 \\
Anabaena variabilis & 0.005 & 0 & $\mathrm{I} \cdot 06$ \\
& 0.005 & $0.00 \mathrm{I}$ & $0.9 \mathrm{I}$ \\
& 0 & 0 & $0.9 \mathrm{I}$ \\
& 0 & $0.00 \mathrm{I}$ & 0 \\
Nostoc muscorum $\mathrm{G}$ & 0.002 & 0 & $\mathrm{I} \cdot 09$ \\
& $0.00 \mathrm{I}$ & 0 & 0.97 \\
& 0.002 & $0.00 \mathrm{I}$ & $1.0 \mathrm{I}$ \\
& 0 & 0 & 0.70 \\
& 0 & $0.00 \mathrm{I}$ & 0 \\
& $0.00 \mathrm{I}$ & 0 & 0.56 \\
& $0.00 \mathrm{I}$ & $0.00 \mathrm{I}$ & 0.68
\end{tabular}

Photoassimilation experiments. The assimilation of acetate. Isotopic tracer studies with ( $\mathrm{I}-$ ) and $(2-)^{14} \mathrm{C}$-acetate were carried out to determine if acetate was assimilated by growing cultures of blue-green algae. Preliminary tests with cell suspensions in growth medium showed that both (I-) and (2- $)^{14} \mathrm{C}$-acetate were assimilated, and that the process was light dependent. The time course of photoassimilation of $(2-)^{14} \mathrm{C}$ acetate followed over a $\mathrm{I} 2 \mathrm{hr}$ incubation period showed a uniform rate of assimilation over the initial $4 \mathrm{hr}$, and over $40 \%$ of the added acetate was incorporated by the cell suspensions after $12 \mathrm{hr}$ incubation (Hoare \& Moore, I965). In order to study in more detail the influence of different factors on the rate of photoassimilation of acetate, conditions were developed such that the rate of photoassimilation was proportional to 
the cell concentration. A series of tubes was set up with a range of cell concentrations. $(2-)^{14} \mathrm{C}$-acetate $(0 \cdot 0 \mathrm{I} \mathrm{M}$ final concentration, $2 \mu \mathrm{C}$.) was added to each tube and samples ( I ml.) were withdrawn after I, 2, 3 and $4 \mathrm{hr}$ incubations and assayed for incorporated radioactivity. For each cell concentration the rate of photoassimilation of ${ }^{14} \mathrm{C}$-acetate was determined. The results are given in Fig. 2. When the tubes were gassed with $\mathrm{I}-2 \%(\mathrm{v} / \mathrm{v}) \mathrm{CO}_{2}$ in air, the rate of acetate incorporation was proportional to concentrations up to $0.5 \mathrm{mg}$. dry weight organisms $/ \mathrm{ml}$. but decreased with higher concentrations. Increasing the carbon dioxide concentration to $4 \%(\mathrm{v} / \mathrm{v})$ increased the range over which the rate of acetate assimilation was proportional to cell concentration but significantly decreased the absolute rate. For all subsequent experiments suspensions of organisms were kept within the range $0.3-0.5 \mathrm{mg}$. dry weight $/ \mathrm{ml}$. and were gassed
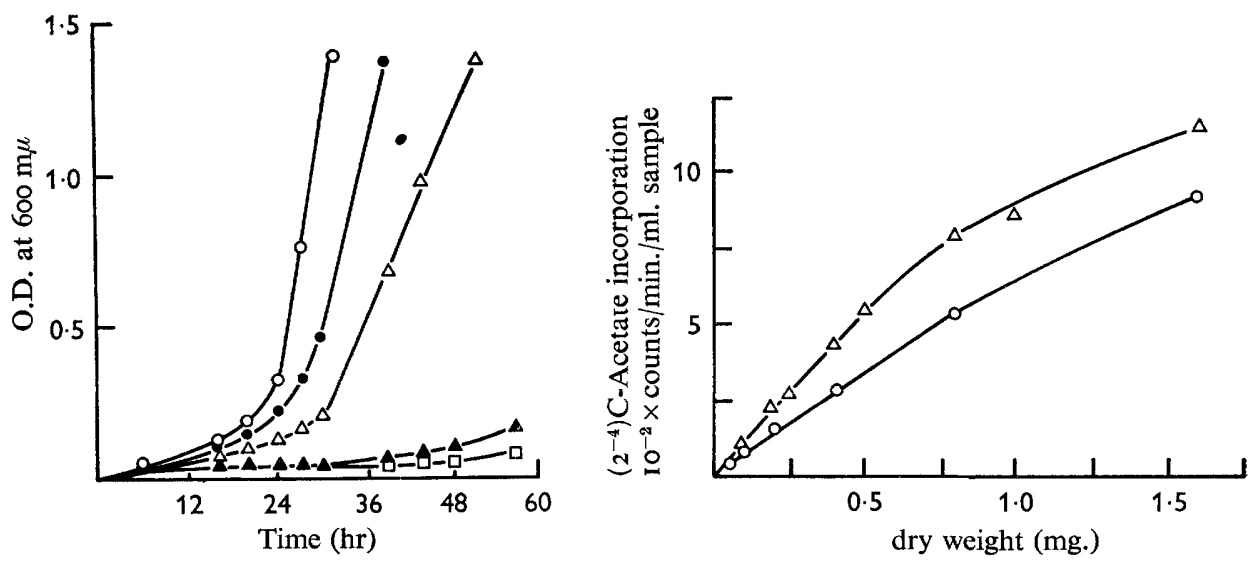

Fig. I. The effect of acetate on the growth of Anacystis nidulans. $20 \mathrm{ml}$. tube cultures inoculated and aerated with $1 \%$ carbon dioxide in air, incubated in the light at $30^{\circ}$ as described in methods. Growth followed at $600 \mathrm{~m} \mu$, basal medium supplemented with different concentrations of acetate: $O-O$ none, $-10^{-2} \mathrm{M} ; \triangle-\triangle 2 \times 10^{-2} \mathrm{M} ; \Delta-\Delta 3 \times 10^{-2} \mathrm{M}$, $\square-\square 4 \times 10^{-2} \mathrm{M}$

Fig. 2. Effect of cell concentration on the rate of photoassimilation of acetate by Anacystis nidulans.

Cell suspensions $(20 \mathrm{ml}$.) of different dry weight concentrations were incubated with sodium $\left(2^{-}\right)^{14} \mathrm{C}$ acetate for periods up to $4 \mathrm{hr}$ and samples ( $\mathrm{I} \mathrm{ml}$.) were withdrawn and assayed for radioactivity as described in Methods. Rates of incorporation are given as counts per minute per ml. suspension. $\triangle-\triangle$ aerated with I \% carbon dioxide in air. $\mathrm{O}-\mathrm{O}$ aerated with $4 \%$ carbon dioxide in air.

with $\mathrm{I}-2 \%(\mathrm{v} / \mathrm{v}) \mathrm{CO}_{2}$ in air unless otherwise stated. The rate of photoassimilation of acetate was found to be carbon dioxide dependent. Cultures gassed with carbon dioxide free air, made by passing air through a tube packed with soda-lime and then through two Milligan gas washers containing $\mathrm{N}$-sodium hydroxide, showed an exceedingly slow rate of acetate assimilation (Fig. 3). The gradual increase in rate of assimilation during the experiment in the cultures gassed with I $\%(\mathrm{v} / \mathrm{v})$ carbon dioxide is probably due to cell growth.

The effect of different experimental conditions on the rate of photoassimilation of acetate by Anancystis nidulans is summarized in Table 2. Acetate assimilation was exceedingly sensitive to inhibition by DCMU (dichlorophenyl, dimethyl urea), which is a potent inhibitor of non-cyclic photophosphorylation and acts by blocking the 
oxygen-evolving system. Acetate was assimilated at the same rate under 'semianaerobic' conditions when the cultures were gassed with a mixture $(I+99$ parts by volume) of carbon dioxide in nitrogen or in hydrogen. Carbon dioxide was still essential for optimal acetate assimilation under these 'semi-anaerobic' conditions. Cell suspensions in nitrogen-free media showed a diminished rate of acetate assimilation, but there was only a slight decrease in acetate assimilation after longer periods of incubation (4-8 hr) with cells suspended in magnesium or phosphate-deficient media. Sodium fluoroacetate at a final concentration of $\mathrm{IO}^{-3} \mathrm{M}$ had little effect on the photoassimilation of acetate. Propionate which was found to be a potent growth inhibitor for the blue-green algae was shown to inhibit the photoassimilation of acetate, but at comparatively high concentrations.

\title{
Table 2. Effect of experimental conditions on the rate of assimilation of acetate by Anacystis nidulans
}

\begin{abstract}
Suspensions of $A$. nidulans ( $\mathrm{mg.} \mathrm{dry} \mathrm{wt} / \mathrm{ml}$.) in $20 \mathrm{ml}$. medium DM containing $\mathrm{Na}$ $(2-)^{14} \mathrm{C}$-acetate $(200 \mu$ moles, $2 \mu \mathrm{c})$ incubated at $30^{\circ}$ in the light and gassed continuously with the mixture indicated. Samples (I ml.) taken after I, 2, 3, and $4 \mathrm{hr}$. incubations for ${ }^{14} \mathrm{C}$ estimations to determine rates of acetate incorporation as described in Methods.
\end{abstract}

Experimental conditions

$\begin{aligned} \text { Expt. I. Control: } & \text { in air }+\mathrm{I} \%(\mathrm{v} / \mathrm{v}) \mathrm{CO}_{2} \\ & +2.5 \times 1 \mathrm{I}^{-7} \mathrm{M}-\mathrm{DCMU} \\ & +5 \times 10^{-7} \mathrm{M}-\mathrm{DCMU} \\ & +7.5 \times 10^{-7} \mathrm{M}-\mathrm{DCMU} \\ & +10^{-6} \mathrm{M}-\mathrm{DCMU}\end{aligned}$

Dark control

Expt. 2. Control: in air $+\mathrm{I} \%(\mathrm{v} / \mathrm{v}) \mathrm{CO}_{2}$ in nitrogen $+\mathrm{I} \%(\mathrm{v} / \mathrm{v}) \mathrm{CO}_{2}$ in nitrogen-deficient media $\left(\operatorname{air}+\mathrm{I} \% \mathrm{CO}_{2}\right)$ in hydrogen $+1 \%(\mathrm{v} / \mathrm{v}) \mathrm{CO}_{2}$

Expt. 3. Control: in air $+\mathrm{I} \%(\mathrm{v} / \mathrm{v}) \mathrm{CO}_{2}$ $+2 \times \mathrm{IO}^{-2} \mathrm{M}-\mathrm{Na}$ propionate $+\mathrm{IO}^{-2} \mathrm{M}-\mathrm{Na}$ propionate $+5 \times 10^{-3} \mathrm{M}-\mathrm{Na}$ propionate $+\mathrm{IO}^{-3} \mathrm{M}-\mathrm{Na}$ propionate
Acetate assimilation $10^{-2} \times$ counts $/ \mathrm{min} . / \mathrm{mg}$. dry wt cells $/ \mathrm{hr}$
$34 \cdot 2$
$33 \cdot 0$
$12 \cdot 6$
$9 \cdot 7$
$6 \cdot 5$
0.2
$33 \cdot 0$
$33 \cdot 0$
$17 \cdot 0$
$33 \cdot 0$
$12 \cdot 4$
$2 \cdot 1$
$4 \cdot 5$
$9 \cdot 7$
I I 5

Photoassimilation of other organic compounds. Anacystis nidulans was also tested for its ability to assimilate a limited number of other simple organic compounds. Test conditions were similar to those employed with acetate, using ${ }^{14} \mathrm{C}-$ labelled compounds. Total incorporated radioactivity was determined after incubations in the light and in the dark. The results are summarized in Table 3.

Propionate incorporation was also tested, but at lower concentrations, since it was a potent growth inhibitor. Both ( $\mathrm{I}-)$ and $(2-)^{14} \mathrm{C}$-propionate were incorporated in a light dependent process and the rate of incorporation, which was linear for $2-3 \mathrm{hr}$, was significantly reduced if the cultures were aerated with carbon dioxide free air. Other organic compounds including butyrate, citrate, glutamate and succinate were not significantly incorporated by Anacystis nidulans.

Distribution of incorporated radioactive compounds. Distribution of incorporated 
radioactivity in Anacystis nidulans was examined using the fractionation procedure of Roberts et al. (1955). Distribution of incorporated acetate was also examined in Anabaena variabilis, Nostoc muscorum G and Anabaena flos-aquae and part of these preliminary findings have already been reported (Hoare \& Moore, 1965). The results with Anabaena flos-aquae which have not been previously reported are given in Table 4.

\section{Table 3. Photoassimilation of organic acids by Anacystis nidulans}

Washed suspensions (Io mg. dry wt organisms/10 ml. medium DM) of photoautotrophically grown $A$. nidulans incubated in the light or in the dark with organic substrates (Na salts, Io $\mu$ moles, $2 \mu \mathrm{C}{ }^{14} \mathrm{C}$ ) gassed continuously with $\mathrm{I} \%(\mathrm{v} / \mathrm{v}) \mathrm{CO}_{2}$ in air, $5 \mathrm{hr}$. at $30^{\circ}$. Total ${ }^{14} \mathrm{C}$ incorporation determined on samples as described in Methods.

$\begin{array}{llcc}\text { Substrate } & \text { Total }{ }^{14} \mathrm{C} & \begin{array}{c}\text { Total }{ }^{14} \mathrm{C} \\ \text { added } \\ 10^{-5} \times \text { counts } \\ \text { min. }\end{array} & \begin{array}{c}\text { assimilated } \\ 10^{-5} \times \text { counts } / \\ \text { min. }\end{array} \\ \text { Acetate } & \text { Light } & 30 \cdot 9 & 20 \cdot 5 \\ \text { Succinate } & \text { Dark } & 29 \cdot 3 & 4 \cdot 0 \\ & \text { Light } & 32 \cdot 5 & 0 \cdot 4 \\ \text { Glutamate } & \text { Dark } & 31 \cdot 3 & 0 \cdot 1 \\ & \text { Light } & 38 \cdot 4 & 0 \cdot 7 \\ \text { Citrate } & \text { Dark } & 35 \cdot 0 & 0 \cdot 5 \\ & \text { Light } & 38 \cdot 9 & 0 \cdot 7 \\ & \text { Dark } & 34 \cdot 6 & 0 \cdot 5\end{array}$

Table 4. Distribution of incorporated ${ }^{14} \mathrm{C}$-acetate by Anabaena flos-aquae

Io ml. medium DM containing $26 \mathrm{mg}$ dry wt organisms incubated $20 \mathrm{hr}$ in the light at $30^{\circ}$ with $\mathrm{Na}(\mathrm{I}-)^{14} \mathrm{C}$-acetate (Io $\mu$ moles, $4 \mu \mathrm{C}$ ) gassed continuously with $\mathrm{I} \%(\mathrm{v} / \mathrm{v}) \mathrm{CO}_{2}$ in air. Organisms harvested, washed and fractionated by the procedure of Roberts et al. (I955) and ${ }^{14} \mathrm{C}$ content of fractions determined.

Fraction

Whole culture (organisms + culture fluid)

1. Cold TCA soluble

2. $75 \%$ ethanol soluble

3. Ethanol/ether soluble

4. Hot TCA soluble

5. Acid ethanol/ether soluble

6. Hydrolyzed residue Total assimilated (sum of $\mathrm{I}-6$ )

\begin{tabular}{cr}
$10^{-5} \times$ counts/min. & \multicolumn{1}{c}{$\% *$} \\
57.0 & - \\
0.47 & 3.2 \\
8.52 & 58.9 \\
0.65 & 4.5 \\
0.34 & $2 \cdot 3$ \\
0.52 & 3.6 \\
4.06 & 28.7 \\
14.56 &
\end{tabular}

$* \%$ of total assimilated.

The 'residual protein' fractions were subjected to further examination. These fractions were hydrolysed in $6 \mathrm{~N}-\mathrm{HCl}\left(\mathrm{I} 8 \mathrm{hr}\right.$ at $\left.\mathrm{IOO}^{\circ}\right)$ and the neutralized hydrolysates were examined by two-dimensional paper chromatography and radioautography as already described (Hoare \& Moore, 1965). In all four blue-green algae, only four amino acids were significantly radioactive, and these were shown to be glutamic acid, proline, arginine and leucine. The protein hydrolysates showed a 'normal' distribution of about sixteen amino acids when the chromatograms were developed with ninhydrin. Separation of the amino acids was achieved on a micro-scale by a combination of high voltage paper electrophoresis and paper chromatography procedures. The 
following more extensive examination of the isolated amino acids was carried out only with Anacystis nidulans.

Specific activities of isolated amino acids. The four radioactive amino acids and aspartic acid were isolated on a micro-scale. Specific activities were determined as follows. Radioactivity of the final amino acid solutions was determined on appropriate samples (in duplicate) in $15 \mathrm{ml}$. Bray solution (Bray, 1960), in an Ansitron liquid scintillation counter. Amino acid estimations were carried out by the colorimetric procedure of Yemm \& Cocking (1954). Since proline gives a very weak colour in this procedure, the modified ninhydrin method of Chinard (1952) was used to estimate proline. The results are given in Table 5 .

Table 5. Specific activities of amino acids derived from $(1-)^{14} C$-acetate in Anacystis nidulans

Amino acids isolated from a hydrolysate of Anacystis nidulans which had incorporated $\mathrm{Na}(\mathrm{I}-)^{\mathrm{I}} \mathrm{C}$-acetate for $\mathrm{I} 8 \mathrm{hr}$ in the light. Amino acids determined by the ninhydrin method of Yemm \& Cocking (1954) and ${ }^{14} \mathrm{C}$ as described in Methods. Specific activity of added $(\mathrm{I}-)^{14} \mathrm{C}$-acetate $4.8 \times \mathrm{IO}^{5}$ counts $/ \mathrm{min} . / \mu \mathrm{mole}$.

Amino acid

Glutamic acid

Aspartic acid

Arginine

Leucine

Proline

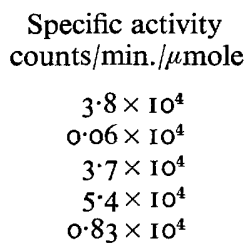

Table 6. Degradation of glutamic acid and leucine derived from $(1-)^{14} C$-acetate in Anacystis nidulans

Amino acids, isolated and purified from a hydrolysate of $A$. nidulans which had incorporated $\mathrm{Na}(\mathrm{I}-)^{14} \mathrm{C}$-acetate for $\mathrm{I} 8 \mathrm{hr}$ in the light, were degraded as described in Methods.

Compound

Glutamate

$\mathrm{CO}_{2}$ (from $\left.\gamma-\mathrm{COOH}\right)$

$\alpha, \gamma$ diaminobutyrate

Leucine

$\mathrm{CO}_{2}$ $\mu$ moles

I, 000
470
I I 2
II 99
I I 99

Specific activity Counts $/ \mathrm{min}$. counts $/ \mathrm{min} . / \mu$ mole

$$
\begin{array}{r}
240,000 \\
\text { I } 10,000 \\
85 \\
80,320 \\
65,400
\end{array}
$$

Degradations of isolated amino acids. Two of the amino acids, formed as a result of the photoassimilation of (I)- ${ }^{14} \mathrm{C}$-acetate by Anacystis nidulans, were degraded to locate the incorporated ${ }^{14} \mathrm{C}$. Leucine was degraded by reaction with an excess of chloramine- $\mathrm{T}$ which decarboxylates the amino acid quantitatively. The reaction was carried out in a Warburg manometer vessel according to the procedure of Kemble \& McPherson (I954) and as used previously by Hoare \& Gibson (I964). Glutamic acid was degraded by a Schmidt reaction in which the amino acid was treated with hydrazoic acid resulting in decarboxylation of the terminal (C-5) or $\gamma$-carboxyl group (Cutinelli, Ehrensvard, Reio, Saluste \& Stjernholm, 195I; Hoare, I963). The residual $\alpha, \gamma$-diaminobutyric acid was recovered from the reaction products as the dipicrate and was subsequently converted to the free amino acid. The results of the degradations are given in Table 6. 
Enzyme activities in cell-free extracts of Anacystis nidulans. The results of the degradation of glutamate are consistent with the conventional pathway of glutamate synthesis from acetate via citrate. Accordingly evidence was sought for the presence, in cell-free extracts of Anacystis nidulans, of all the enzymes necessary to effect the incorporation of acetate into glutamic acid. Cell-free extracts were prepared as described in the Methods section, and the following enzymic activities were clearly established.

Table 7. Acetyl CoA synthetase in cell-free extracts of Anacystis nidulans

\begin{tabular}{|c|c|c|c|}
\hline Substrate & Component omitted & $\begin{array}{c}\text { Incubation } \\
\text { time } \\
\text { (min.) }\end{array}$ & $\begin{array}{c}\text { Hydroxamate } \\
\text { formed } \\
\text { absorbance at } \\
540 \mathrm{~m} \mu\end{array}$ \\
\hline Acetate & None & 60 & 0.276 \\
\hline Propionate & None & 60 & 0.193 \\
\hline Butyrate & None & 60 & 0.040 \\
\hline Fluoroacetate & None & $\begin{array}{r}60 \\
90 \\
120 \\
200\end{array}$ & $\begin{array}{l}0.077 \\
0.093 \\
0.110 \\
0.140\end{array}$ \\
\hline Propionate & $\begin{array}{l}\mathrm{CoA} \\
\text { ATP } \\
\mathrm{MgCl}_{2} \\
\text { Glutathione }\end{array}$ & $\begin{array}{l}60 \\
60 \\
60 \\
60\end{array}$ & $\begin{array}{l}0.053 \\
0.038 \\
0.124 \\
0.145\end{array}$ \\
\hline
\end{tabular}

(i) Acetic thiokinase (acetyl CoA synthetase). Cell-free extracts catalysed an ATP and coenzyme A dependent formation of a hydroxamic acid from acetate. Propionate was also activated but no hydroxamate was formed with butyrate as substrate. Propionate appeared to compete with acetate in these reactions. Sodium fluoroacetate was only poorly activated by extracts of Anacystis nidulans. Typical results are summarized in Table 7 .

(ii) Citrate synthase. Using cell-free extracts supplemented with all the co-factors necessary for optimal activity of the acetic thiokinase, but with the neutralized hydroxylamine omitted, it was possible to demonstrate the formation of citrate provided oxaloacetate was added. This was demonstrable in two ways. In the first procedure $(2-)^{14} \mathrm{C}$-acetate was used as a substrate, whereby an oxaloacetate dependent incorporation of radioactivity into a non-volatile acidic fraction could be demonstrated. Radioactivity was extracted into ether from acid solution and two-dimensional chromatograms with carrier citrate showed coincidence between the carrier and radioactive areas on the chromatogram. Coincidence of added carrier citrate and radioactivity was also established by paper electrophoresis at $\mathrm{pH} 3 \cdot 6$. The chromatography system of Benson et al. (1950) was used. In the second procedure, citrate formed as a result of incubation under the conditions of the previous procedure, or alternatively using acetylcoenzyme A (prepared by the method of Stadtman, 1957) in place of the acetic thiokinase system, was measured directly by the colorimetric procedure of Taylor 
(1953). Typical results are given in Table 8. Using acetylcoenzyme A as substrate attempts to establish a correlation between the amount of acetylcoenzyme A used, followed by measuring the absorption of deproteinized solutions at $260 \mathrm{~m} \mu$, or by hydroxamate formation, and citrate formation were not successful due to variable degrees of breakdown of acetylcoenzyme A by crude extracts in the absence of oxaloacetate.

\section{Table 8. Citrate synthase in cell-free extracts of Anacystis nidulans}

Complete reaction mixtures $2 \mathrm{ml}$. contained cell-free extract ( $2 \mathrm{mg}$. dry wt), $200 \mu$ moles $\mathrm{K}(2-)^{14} \mathrm{C}$-acetate $\left(17 \times 10^{5}\right.$ counts $/ \mathrm{min}$.), $0.16 \mu$ moles CoA, $20 \mu$ moles ATP, $200 \mu$ moles K phosphate ( $\mathrm{pH} 7 \cdot 5$ ), $20 \mu$ moles $\mathrm{MgCl}_{2}, 20 \mu$ moles glutathione, and $20 \mu$ moles $\mathrm{K}$ oxaloacetate. Tubes incubated at $35^{\circ}$, roo $\mu \mathrm{l}$. samples removed at times indicated, mixed with $100 \mu 1.2 \%(\mathrm{w} / \mathrm{v})$ acetic acid, dried on planchettes and assayed for ${ }^{14} \mathrm{C}$.

$\begin{array}{cccc}\begin{array}{c}\text { Incubation } \\ \text { (min.) }\end{array} & \text { Complete } & \begin{array}{c}\text { Coenzyme A } \\ \text { omitted }\end{array} & \begin{array}{c}\text { Oxaloacetate } \\ \text { omitted }\end{array} \\ 20 & 22 \cdot 7 & 4 \cdot 9 & 4 \cdot 4 \\ 40 & 45 \cdot 7 & 7 \cdot 6 & 9 \cdot 3 \\ 60 & 70 \cdot 1 & 9 \cdot 1 & 9 \cdot 9 \\ 90 & 84 \cdot 0 & 8 \cdot 1 & 10 \cdot 1 \\ 120 & 128 \cdot 5 & 13 \cdot 9 & 19 \cdot 7 \\ 180 & 166 \cdot 4 & 18 \cdot 4 & 19 \cdot 7\end{array}$

Table 9. Aconitase and isocitrate dehydrogenase in cell-free extracts of Anacystis nidulans

Cell-free extract of $A$. nidulans ( $1.6 \mathrm{mg}$. dry wt) incubated at $35^{\circ}$ in a reaction mixture of $3 \mathrm{ml}$. containing ( $\mu$ moles): $0.5 \mathrm{~K}$-DL-isocitrate, $0.5 \mathrm{NADP}, 10 \mathrm{MgCl}_{2}$, $100 \mathrm{~K}$ phosphate $(\mathrm{pH} 7 \cdot 0)$. For stoichiometry, lower concentrations of isocitrate were used as indicated.

(a) Stoichiometry
D-isocitrate
( $\mu$ moles)
0.06
0.12
0.18
0.24

(b) Reaction rates:

Components
Complete:
DL-isocitrate and NADP
cis-aconitate and NADP
Citrate and NADP
DL-isocitrate and NAD
DL-isocitrate, NADP; $\mathbf{M g}^{2+}$ omitted

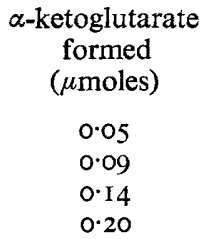

$\triangle \mathrm{OD}$ at $340 \mathrm{~m} \mu / \mathrm{min} . / \mathrm{mg}$. dry wt

$$
\begin{aligned}
& 0.105 \\
& 0.035 \\
& <0.005 \\
& \mathrm{Nil} \\
& 0.020
\end{aligned}
$$

(iii) Aconitate hydratase (aconitase) and iso-citrate NADP dehydrogenase. As outlined in Methods, aconitate hydratase was demonstrated indirectly by using cis-aconitate as substrate under the spectrophotometric assay conditions for isocitrate NADP dehydrogenase. Iso-citrate dehydrogenase was readily demonstrated in extracts and was shown to be activated by magnesium, even in undialyzed extracts. The reaction was NADP specific, and stoichiometry was established between iso- 
citrate disappearance (assumed to be complete when the reaction ceased with an excess of NADP), NADP reduced and $\alpha$-ketoglutarate formed. Results are summarized in Table 9.

(iv) Conversion of $\alpha$-ketoglutarate to glutamate. It was at first assumed that glutamate would be formed from $\alpha$-ketoglutarate through the action of a pyridine nucleotide linked glutamate dehydrogenase. Numerous attempts to assay for L-glutamate dehydrogenase, using NAD or NADP as coenzyme, were unsuccessful. The reaction was tested in the synthetic direction by seeking a glutamate dependent oxidation of the reduced pyridine nucleotides, by spectrophotometric measurements at $340 \mathrm{~m} \mu$. It was also tested in the reverse direction by spectrophotometry at $340 \mathrm{~m} \mu$, and by seeking the formation of $\alpha$-ketoglutarate by the 2,4-dinitrophenyl hydrazone procedure of Friedmann (I957). Whilst it is probably not justified to conclude that Anacystis nidulans lacks a glutamate dehydrogenase, alternative mechanisms for glutamate formation were sought. Qualitative tests, as outlined in Methods, readily established that glutamate was formed from $\alpha$-ketoglutarate by transamination with appropriate L-amino acids. The most effective amino acids for the transamination reaction were the branched chain amino acids leucine, isoleucine and valine; phenylalanine and aspartic acid were less effective amino donors.

(v) Conversion of glutamate to ornithine. Evidence for the conversion of glutamate to ornithine by a transacetylation mechanism in a number of blue-green algae and photosynthetic bacteria was presented recently by Hoare \& Hoare (1966). Extracts of blue-green algae were shown to contain a transacetylase which catalysed the reversible transfer of an acetyl group from $\alpha-N$-acetyl-L-ornithine to L-glutamate, and to contain an $\mathrm{N}$-acetyl glutamate phosphokinase which is specifically inhibited by L-arginine. These findings support the proposition that arginine is synthesized from L-glutamate via acetylated derivatives in some blue-green algae. Further evidence in support of the postulated enzymic pathway was sought by attempting to demonstrate the presence, in cell-free extracts of Anacystis nidulans, of other enzymes catalyzing reactions involving certain acetylated intermediates. The postulated sequence of reactions involving acetylated intermediates is as follows:

(i) L-glutamate + acetylcoenzyme $\mathrm{A} \rightarrow N$-acetyl-L-glutamic acid.

(ii) $N$-acetyl-L-glutamic acid + ATP $\rightarrow N$-acetyl-L-glutamyl- $\gamma$-phosphate + ADP.

(iii) $N$-acetyl- L-glutamyl- $\gamma$-phosphate $+\mathrm{NADPH}+\mathrm{H}^{+} \rightarrow N$-acetyl-L-glutamyl- $\gamma$ semi-aldehyde.

(iv) $N$-acetyl-L-glutamyl- $\gamma$-semi - aldehyde + glutamate $\rightarrow \alpha$-ketoglutarate $+\alpha-N$ acetyl-L-ornithine.

(v) $\alpha$ - $N$-acetyl-L-ornithine + glutamate $\rightarrow$ L-ornithine $+N$-acetyl-L-glutamic acid.

As pointed out by Hoare \& Hoare (1966), this sequence of reactions for the biosynthesis of ornithine from glutamic acid involves a cycle of acetylated intermediates in which $\mathrm{N}$-acetyl-L-glutamic acid is required in only catalytic amounts. Attempts to demonstrate an appreciable synthesis of $N$-acetyl-L-glutamic acid by the procedures of Maas, Novelli \& Lipmann (1953) or of Hudock (1962) were not successful. It was, however, possible to demonstrate qualitatively the formation of $\mathrm{N}$-acetyl glutamic acid using $(2-)^{14} \mathrm{C}$-acetate as substrate in a system containing all reactants necessary for the conversion of acetate to acetylcoenzyme A supplemented with L-glutamic acid. Reaction mixtures of $\mathrm{I} \cdot 5 \mathrm{ml}$. final volume contained ( $\mu$ moles): 0.08 coenzyme $\mathrm{A}$; Io NaATP; Io glutathione; Io potassium acetate, (I0 $\mu \mathrm{C})$; Ioo potassium phosphate 
buffer $\mathrm{pH} 7.5$; $10 \mathrm{MgCl}_{2} ; 5$ sodium glutamate; cell-free extract containing $8 \mathrm{mg}$. protein. Tubes were incubated $60 \mathrm{~min}$. at $35^{\circ}$ and the reaction was stopped by immersing tubes in a boiling water bath for $5 \mathrm{~min}$. Control tubes were run in which glutamate was omitted, and in which the complete reaction mixture was stopped at zero time. Ten $\mu$ moles carrier $N$-acetyl glutamate was added to the cooled tubes which
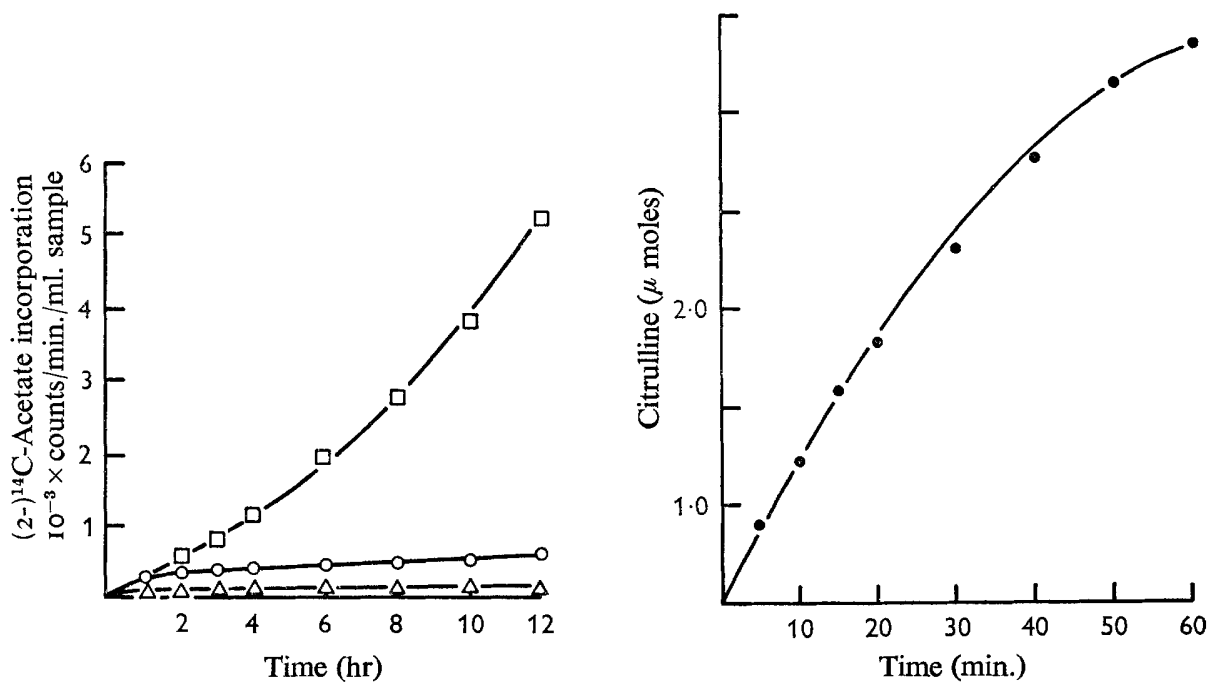

Fig. 3. Effect of carbon dioxide on the photoassimilation of acetate by Anacystis nidulans. Cell suspensions $(0.38 \mathrm{mg}$. dry wt per $\mathrm{ml}$.) were incubated as described with sodium $(2-)^{14} \mathrm{C}$-acetate and samples ( $\mathrm{I} \mathrm{ml}$.) withdrawn at intervals for assay of incorporated radioactivity. $\square-\square$ control illuminated system aerated with $1 \%$ carbon dioxide in air; $0-0$ system illuminated and aerated with carbon dioxide free air; $\triangle-\Delta$ dark control aerated with $1 \%$ carbon dioxide in air.

Fig. 4. Time course of citrulline formation from carbamyl phosphate and ornithine in cellfree extracts of Anacystis nidulans. Cell-free extract containing $2 \mathrm{mg}$. protein incubated in a final volume of $\mathrm{I} \mathrm{ml}$. under conditions given in the methods.

Table 10. $\alpha$-N-acetyl ornithine transaminase in extracts of Anacystis nidulans

$\begin{array}{ccc}\text { Substrate } & \begin{array}{c}\text { Incubation } \\ \text { (min.) }\end{array} & \begin{array}{c}\text { Absorbance } \\ \text { at } 440 \mathrm{~m} \mu\end{array} \\ \alpha-N \text {-acetyl-L-ornithine } & \text { I5 } & 0.06 \\ & 30 & 0.10 \\ & 60 & 0.15 \\ & 90 & 0.21\end{array}$

Cell-free extract of $A$. nidulans ( $2 \mathrm{mg}$. protein) incubated at $35^{\circ}$ in a reaction mixture of I ml. containing ( $\mu$ moles): $5 \alpha-N$-acetyl-L-ornithine, Io $\alpha$-ketoglutarate, 0.05 pyridoxal phosphate, I0O K phosphate ( $\mathrm{pH} 8 \cdot 0$ ). Figures are corrected for 'controls' without $\alpha$-ketoglutarate. Details given in Methods.

were then treated with $O \cdot I$ vols. $\mathrm{IO} \mathrm{N}_{2} \mathrm{H}_{2} \mathrm{SO}_{4}$, centrifuged, and the clear supernatants were extracted three times with $\mathrm{I} \cdot 5 \mathrm{vol}$. chloroform $+n$-butanol $(\mathrm{I}+4 \mathrm{~V} / \mathrm{v})$. Combined butanol extracts were taken to dryness in a stream of air at $45-50^{\circ}$ and the residues were applied to Whatman $3 \mathrm{MM}$ paper and subjected to electrophoresis at $\mathrm{pH} 3.6$ as previously described (Hoare \& Hoare, 1966). The dried paper was then monitored for ${ }^{14} \mathrm{C}$. Low but significant incorporation of radioactivity was observed in the $N$-acetyl 
glutamic acid area (which could be located by spraying the paper with bromcresol green indicator) only in tubes incubated with the complete reaction mixture. However, acetate incorporation was estimated to be less than $5 \%$ of the acetate added to the system. Although variations in the experimental conditions were examined, no improvement in the net synthesis of $N$-acetyl glutamic acid was achieved and further attempts to establish the presence of the $N$-acetyl glutamate synthetase were abandoned.

The transamination of $\alpha-N$-acetyl ornithine (reaction (iv) in the above reaction sequence) was demonstrated in cell-free extracts of Anacystis nidulans by the procedure of Albrecht \& Vogel (1964). However, it was also found that ornithine participated in a $\gamma$-transamination reaction. The significance of the latter reaction is not clear (Table Io). Extracts of blue-green algae do not contain $\alpha-N$-acetyl ornithine deacetylase.

(vi) Citrulline formation from ornithine. Citrulline was presumed to be an intermediate in arginine biosynthesis, therefore ornithine transcarbamylase activity was examined in extracts of Anacystis nidulans as described in Methods. Typical results are illustrated in Fig. 4. This reaction has also been reported in Nostoc muscorum by Holm-Hansen \& Brown (I963).

\section{DISCUSSION}

The most significant outcome of our limited survey of acetate assimilation by bluegreen algae has been the discovery of a uniquely limited distribution of incorporated acetate into cell constituents. In all cases acetate was incorporated mainly into the lipid fraction and, to a smaller extent, into the cell proteins. The lipid fraction was not examined in detail. However, Nichols, Harris \& James (I965) have recently examined the lipids of the blue-green algae Anacystis nidulans and Anabaena variabilis and have shown that acetate is incorporated into the fatty acids of the lipids: especially into phosphatidyl glycerol. Palmitate, stearate and oleate were also incorporated into lipids. Evidently blue-green algae are not impermeable to these long chain fatty acids.

Acetate incorporation into the protein fraction is of particular interest, since only four amino acids (glutamate, arginine, proline and leucine) were significantly radioactive following the assimilation of $(\mathrm{I}-)$ and $(2-)^{14} \mathrm{C}$-acetate. This situation appears, so far, to be unique to the blue-green algae. The obligately autotrophic green sulphur bacteria of the genus Chlorobium incorporate acetate into all the amino acids of the cell proteins (Hoare \& Gibson, I964).

The degradation data for glutamate and leucine are consistent with established mechanisms for the biosynthesis of these amino acids. There is no need to invoke the operation of any novel mechanism of amino acid biosynthesis in blue-green algae. The conventional route for the biosynthesis of glutamate from acetate is supported by the demonstration, in cell-free extracts of blue-green algae, of all the enzymes necessary to catalyze the over-all reaction. The failure to detect a glutamate dehydrogenase is somewhat disturbing since this enzyme is important in the assimilation of inorganic nitrogen in most micro-organisms. It seems more probable that the transaminases which we have demonstrated qualitatively are involved in the terminal stages of the biosynthesis of other amino acids using glutamate as the amino donor. Biosynthesis of the branched chain amino acids (valine, isoleucine, and leucine) presumably 
involves such transaminases in blue-green algae. Previous claims of the absence of fructose I,6-diphosphate aldolase in blue-green algae (Richter, 196I; Fewson, Al-Hafidh \& Gibbs, I962) and the subsequent demonstration of the enzyme (van Baalen, I965a; Willard, Schulman \& Gibbs, 1965) make it clear that the failure to detect an enzyme in cell-free extracts should be treated with reservation.

Formation of the other three amino acids (i.e. leucine, proline and arginine) from acetate is believed to proceed by conventional routes. Thus leucine is believed to be formed by a condensation of acetylcoenzyme A with $\alpha$-ketoisovaleric acid yielding $\alpha$-isopropyl malic acid, with subsequent transformations according to the following scheme:

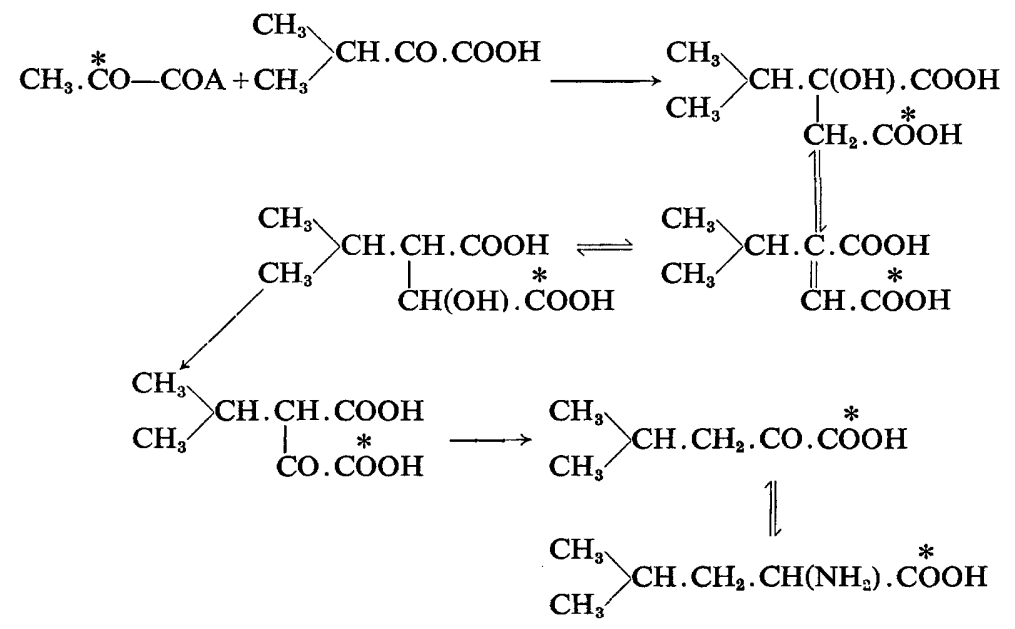

Apart from the presence of transaminases catalyzing the terminal step, no enzyme studies have been carried out on the mechanism of leucine biosynthesis, and support for the above scheme rests almost entirely on the isotope degradation data (Table 7). The above scheme results in the incorporation of the carboxyl (C-I) of acetate into the carboxyl group of leucine. Proline and arginine are believed to be derived from glutamic acid. Enzymes involved in proline biosynthesis have not been extensively examined in blue-green algae. In the course of our studies of $\mathrm{N}$-acetylglutamate phosphokinase, it was found that extracts catalyzed a slower rate of formation of a hydroxamate from glutamate. However, it is not clear whether this is due to a glutamate $\gamma$-phosphokinase which would be involved in the biosynthesis of proline (Baich \& Pierson, I965) or due to a glutamine synthetase (Ravel, Humphreys \& Shive, I965). Evidence in favour of the mechanisms of conversion of glutamate to arginine is more substantial although still lacking in detail. This may be summarized as follows: (I) the specific activities of arginine and glutamate are very similar; (2) a number of enzymes catalyzing the interconversion of acetylated intermediates and the presence of ornithine transcarbamylase have been demonstrated in cell-free extracts of blue-green algae and (3) the $N$-acetyl-L-glutamate phosphokinase is specifically inhibited by arginine.

Since glutamate biosynthesis involves some of the reactions of the tricarboxylic acid cycle it is rather suprising that acetate is not incorporated into aspartic acid and amino acids derived therefrom. This may be compared with the studies of acetate incorporation by glucose grown Escherichia coli (Roberts et al. 1955). In numerous 
experiments apartic acid was isolated from the proteins of blue-green algae which had assimilated (I-) or $(2-)^{14} \mathrm{C}$-acetate, but its specific activity was exceedingly low. The results suggest that the flow of assimilated acetate proceeds more rapidly from $\alpha$-ketoglutarate to glutamate than from $\alpha$-ketoglutarate to succinate and round the tricarboxylic acid cycle to oxaloacetate from which aspartate is presumably derived. This further implies that the tricarboxylic acid cycle may be 'sluggish' in blue-green algae. Blue-green algae do respire at a slow rate, but little is known about their respiratory mechanisms (see, for example, Kratz \& Myers, $1955 b$; Webster \& Frenkel, 1953). Preliminary studies by Still \& Wang (1965) on the role of the tricarboxylic acid cycle in the chemoautotrophic bacterium Thiobacillus thioparus merit comparison with the blue-green algae. Aseptic radio-respirometry techniques showed a number of organic compounds were utilized, although carbon dioxide was still the exclusive carbon source for proliferating cells. Most of the reactions of the tricarboxylic acid cycle were involved in the biosynthesis of the carbon skeletons of amino acids, but cells were unable to convert $\alpha$-ketoglutarate to succinyl coenzyme A. Absence of this enzyme system in the blue-green algae would provide a reasonable explanation for the failure to get acetate incorporated into aspartate and would establish a close relationship between an obligate chemosynthetic bacterium and the obligately photoautotrophic blue-green algae.

Assimilation of organic compounds by blue-green algae was originally studied with the aim of understanding the general problem of obligate autotrophy. Obligate autotrophs as defined by organisms which appear to be unable to grow on organic compounds as sole or major source of cell carbon include some of the chemosynthetic bacteria, photosynthetic bacteria (viz. the genus Chlorobium) and probably most of the blue-green algae. Unfortunately comparatively few studies have been made of the assimilation of organic compounds by obligate autotrophs, and it is still far from clear why such organisms are unable to grow on organic compounds. In green sulphur bacteria of the genus Chlorobium, inability to grow on acetate as sole or major carbon source is probably attributable to the inability of these organisms to oxidize acetate, as was first suggested by Sadler \& Stanier (I960). In Chlorobium, acetate assimilation is not only light dependent, but requires carbon dioxide and an inorganic reductant such as hydrogen sulphide which is the essential source of reducing power for cell synthesis. Formation of essential cell constituents from acetate in Chlorobium is then effected primarily through the pyruvate synthase reaction as was first indicated by the isotope incorporation studies of Hoare \& Gibson (1964). Recent enzyme studies with Chlorobium thiosulphatophilum have established the importance of pyruvate synthase and other carboxylation reactions in this organism (Evans \& Buchanan, 1965; Buchanan \& Evans, 1965; Evans, Buchanan \& Arnon, 1966; Buchanan \& Evans, 1966).

Assimilation of organic compounds by blue-green algae has been studied by a limited number of investigators. Heterotrophic growth of blue-green algae in the dark was first clearly demonstrated by Harder (I9I7) with a strain of Nostoc punctiforme isolated from the rhizomes of the plant Gunnera. However, subsequent investigations have shown that the few blue-green algae which can grow heterotrophically in the dark grow under such conditions at exceedingly slow rates. Thus Allison, Hoover \& Morris ( I937) observed slow growth and nitrogen fixation by a strain of $N$. muscorum in the dark on a glucose medium, and more recently Fay (1965) observed growth and nitro- 
gen fixation by Chlorogloea fritschii heterotrophically in the dark with sucrose as the most effective organic carbon source. Sucrose assimilation (and nitrogen fixation) were greater in the light than in the dark, but, in contrast to our findings on the photoassimilation of acetate, the photoassimilation of sucrose by $C$. fritschii was increased if carbon dioxide was omitted. Heterotrophic growth of Tolypothrix tenuis was first studied by Kiyohara, Fujita, Hattori \& Watanabe (1960); this organism can respire on glucose and can assimilate glucose into a glucose containing polysaccharide (Cheung \& Gibbs, 1966). The most thorough studies on the assimilation of organic compounds by blue-green algae were those of Allison et al. (I953), using radioactive tracer techniques to follow the assimilation of acetate by a strain of $N$. muscorum. Both carbon atoms of acetate were assimilated, and assimilation was greatly stimulated by light and the presence of carbon dioxide. Acetate was incorporated primarily into lipids and into free soluble glutamate and carboxylic acids; the proteins of the cells were not examined. Our studies of acetate assimilation are in accord with these findings. Furthermore, we have found light-dependent acetate assimilation to be inhibited by low concentrations of DCMU, suggesting that the photosynthetic oxygen evolving system is essential. We interpret this to imply that non-cyclic photophosphorylation is essential for acetate assimilation in blue-green algae. DCMU inhibition of the photoassimilation of acetate has been found in eucaryotic algae including species of the genera Chlorella, Scenedesmus, Ankistrodesmus, Chlamydomonas, Chlorogonium and Euglena (Wiessner, I964).

Preliminary reports of acetate assimilation by Anacystis nidulans and Anabaena variabilis by Carr \& Pearce (I966) and Pearce \& Carr (I966) partly corroborate our findings.

From our very limited survey of the assimilation of organic compounds by bluegreen algae, acetate is the most readily assimilated organic compound. This was also the case with the blue-green alga Anabaena flos-aquae studied by Moore \& Tischer (1965), the chemosynthetic sulphur bacterium Thiobacillus thiooxidans studied by Butler \& Umbreit (1966) and the chemosynthetic nitrifying bacterium Nitrobacter agilis studied by Delwiche \& Finstein (I965) and by Ida \& Alexander (1965). Recent preliminary studies by Kelly $(\mathrm{I} 965 a, b)$ of acetate assimilation by T. neapolitanus, in which acetate incorporation was thiosulphate-dependent and in which glutamate formation from acetate was inhibited by fluoroacetate, again indicate remarkably close similarities between obligate chemoautotrophs, at least as exemplified by thiobacilli, and obligate autotrophs, as exemplified by the blue-green algae.

The biochemical mechanism of the inhibitory effect of propionate on the growth of blue-green algae is still not clear. Propionate alone amongst a series of fatty acids inhibited growth. One possible explanation of this specificity and mechanism of growth inhibition would be that propionate 'drains off' coenzyme A which is essential for biosynthetic processes associated with cell growth. The acetothiokinase of Anacystis nidulans was found to activate propionate, but not other fatty acids. Reversal of propionate inhibition by acetate might then be due to the preferential activation of acetate in the presence of propionate, thus making acetylcoenzyme A (presumably normally generated from pyruvate) available for essential biosynthetic reactions. Growth inhibition by propionate and its reversal by acetate was observed in the bacterium Streptococcus faecalis by Hill (1952). Propionate inhibition of the growth of the eucaryotic alga Haematococcus pluvialis has been reported by Stross (I960). 
This work was supported by Public Health Service Grants AI-06447 and GM 600 from the National Institutes of Health, by funds from the University Research Institute of The University of Texas and by a Public Health Service Water Resources Traineeship to R. B. Moore. The technical assistance of Mr J. LaMontaigne and Miss Susan Pais is gratefully acknowledged. We are also indebted to Dr J. Myers of the Zoology Department of The University of Texas for providing large-scale cultures of Anacystis nidulans. Dr R. Tischer of the Bacteriology Department of Mississipi State University kindly provided a culture of Anabaena flos-aquae A 37.

\section{REFERENCES}

Albrecht, A. M. \& Vogel, H. J. (1964). Acetyl ornithine $\delta$-transaminase. Partial purification and repression behaviour. J. biol. Chem. 239, I872.

Allison, F. E., Hoover, S. R. \& MorRIS, J. H. (1937). Physiological studies with the nitrogen fixing alga Nostoc muscorum. Botan. Gaz. 98, 433.

Allison, R. K., Skipper, H. E., Reid, M. R., Short, W. A. \& Hogan, G. L. (1953). The assimilation of acetate by Nostoc muscorum. J. biol. Chem. 204, 197.

ARCHIBALD, R. M. (1944). Determination of citrulline and allantoin and demonstration of citrulline in blood plasma. J. biol. Chem. 156, I2I.

VAN BAALEN, C. (1965a). Quantitative surface plating of coccoid blue-green algae. J. Phycol. r, ig. van BAALen, C. (1965b). Aldolase in blue-green algae. Nature, Lond. 206, 193.

Baich, A. \& Pierson, D. J. (1965). Control of proline biosynthesis in Escherichia coli. Biochim. Biophys. Acta 104, 397.

Benson, A. A., Bassham, J. A., Calvin, M., Goodale, T. C., Haas, W. \& Stepka, W. (1950). Path of carbon in photosynthesis: V. Paper chromatography and radioautography of the products. J. Am. chem. Soc. 72, I710.

BRAY, G. A. (1960). A simple efficient liquid scintillator for counting aqueous solutions in a liquid scintillation counter. Analyt. Biochem. I, 279.

Buchanan, B. B. \& Evans, M. C. W. (1965). The synthesis of $\alpha$-ketoglutarate from succinate and carbon dioxide by a sub-cellular preparation of a photosynthetic bacterium. Proc. natn. Acad. Sci., U.S.A. 54, $12 \mathrm{I} 2$.

Buchanan, B. B. \& Evans, M. C. W. (1966). The synthesis of phosphoenol pyruvate and ATP by extracts of photosynthetic bacteria. Biochem. biophys. Res. Comm. 22, 484.

ButLER, R. G. \& UMBReIT, W. W. (I966). Absorption and utilization of organic matter by the strict autotroph Thiobacillus thiooxidans, with special reference to aspartic acid. J. Bact. 91, 66I.

Carr, N. G. \& Pearce, J. (I966). Photoheterotrophism in blue-green algae. Biochem. J. 99, 28 P.

Cheung, W. Y. \& GibBs, M. (1966). Dark and photometabolism of sugars by a blue-green alga: Tolypothrix tenuis. Plant Physiol. 4I, 73I.

ChinaRd, F. P. (1952). Photometric estimation of proline and ornithine. J. biol. Chem. 199, 9I.

Cutinelil, C., Ehrensvard, G., Reio, L., Saluste, E. \& Stjernholm, R. (1951). Acetic acid metabolism in Escherichia coli. I. General features, and the metabolic connection between acetate and glutamic acid, aspartic acid, glycine, alanine, valine, serine and threonine. Acta chem. scand. 5, 353 .

Delwiche, C. C. \& Finstein, M. S. (1965). Carbon and enzyme sources for the nitrifying autotroph Nitrobacter. J. Bact. 90, 102.

Dixon, G. H., Kauffman, D. L. \& Neurath, H. (1958). Amino acid sequence in the region of diisopropylphosphoryl binding in diisopropylphosphoryl trypsin. J. biol. Chem. 233, 1373.

Evans, M. C. W. \& Buchanan, B. B. (1965). Photoreduction of ferredoxin and its use in carbon dioxide fixation by a subcellular system from a photosynthetic bacterium. Proc. natn. Acad. Sci. U.S.A. $53,1420$.

Evans, M. C. W., Buchanan, B. B. \& Arnon, D. I. (1966). A new ferredoxin-dependent carbon dioxide reduction cycle in a photosynthetic bacterium. Proc. natn. Acad. Sci. U.S.A. 55, 928.

FAY, P. (1965). Heterotrophy and nitrogen fixation in Chlorogloea fritschii. J. gen. Microbiol 39, II. 


\section{Photoassimilation in blue-green algae}

Fewson, C. A., Al-Hafidh, M. \& Gibbs, M. (I962). Role of aldolase in photosynthesis. I. Enzyme studies with photosynthetic organisms with special reference to blue-green algae. Plant Physiol. 37, 402 .

Friedmann, T. E. (1957). Determination of $\alpha$-keto acids. Meth. Enzymol. 3, 414.

HARDER, R. (I9I7). Ernährungsphysiologische Untersuchungen an Cyanophyceen, hauptsächlich dem endophytischen Nostoc. punctiforme. Z. Botan. 9, 145.

HrLl, C. H. (I952). Studies on the inhibition of growth of Streptococcus faecalis by sodium propionate. J. biol. Chem. 199, 329.

HoARE, D. S. (1963). The breakdown and biosynthesis of glutamic acid. J. gen. Microbiol. $32,157$.

HoARE, D. S. \& Gibson, J. (I964). Photoassimilation of acetate and the biosynthesis of amino acids by Chlorobium thiosulphatophilum. Biochem. J. 9r, 546.

HoARE, D. S. \& MoOre, R. B. (1965). Photoassimilation of organic compounds by autotrophic bluegreen algae. Biochem. biophys. Acta Iog, 622.

Hoare, D. S., Hoare, S. L. \& Moore, R. B. (1966a). Photosynthesis of amino acids from acetate in an autotrophic blue-green alga. Proc. Am. Soc. Microbiol. p. 73.

Hoare, D. S., Hoare, S. L. \& Moore, R. B. (I966 b). Photosynthesis of amino acids from acetate by blue-green algae. Abstr. int. Congr. Microbiol. 9. I57.

HOARE, D. S. \& HOARE, S. L. (1966). Feedback regulation of arginine biosynthesis in blue-green algae and photosynthetic bacteria. J. Bact. 92, 375.

Holm-Hansen, O. \& Brown, G. W. (1963). Ornithine cycle enzymes in the blue-green alga Nostoc muscorum. Plant and Cell Physiol. 4, 299.

Hudock, G. A. (1962). Formation of $N$-acetyl glutamate in Chlamydomonas reinhardii. Biochem. biophys. Res. Comm. 9, $55 \mathrm{I}$.

IdA, S. \& AleXAnder, M. (I965). Permeability of Nitrobacter agilis to organic compounds. J. Bact. 90, $15 \mathrm{I}$.

Jones, M. E. \& LipMann, F. (1955). Aceto-Co-A-kinase. Meth. Enzymol. 1, 585.

Kelly, D. P. (1965a). Assimilation of organic compounds by a strictly chemoautotrophic Thiobacillus. J. gen. Microbiol. 4r, v.

KeLly, D. P. (1965b). Influence of organic compounds on Thiobacillus. Biochem. J, Ioo, 9P.

Kemble, A. R. \& McPherson, H. T. (1954). Determination of monoamino monocarboxylic acids by quantitative paper chromatography. Biochem. $J .56,548$.

Kiyohara, T., Fujita, Y., Hattori, A. \& Watanabe, A. (I960). Heterotrophic culture of a bluegreen alga, Tolypothrix tenuis. J. gen. appl. Microbiol. 6, 176.

Kratz, W. A. \& MYers, J. (1955a). Nutrition and growth of several blue-green algae. Am. J. Botan. 42, 282.

Kratz, W. A. \& Myers, J. (1955b). Photosynthesis and respiration of three blue-green algae. Plant Physiol. 30, 275.

Lipmann, F. \& Tutrle, L. C. (1945). A specific micromethod for the determination of acyl phosphates. J. biol. Chem. 159, 2 I.

MaAs, W. K., Novelli, G. D. \& LipmanN, F. (I953). Acetylation of glutamic acid by extracts of Escherichia coli. Proc, natn. Acad. Sci. U.S.A. 39, 1004.

Moore, B. G. \& Tischer, R. G. (1965). Biosynthesis of extracellular polysaccharides by the bluegreen alga Anabaena flos-aquae. Can. J. Microbiol. Ir, 877.

Myers, J. \& ClaRK, L. B. (I944). Culture conditions and the development of the photosynthetic mechanism. II. An apparatus for the continuous culture of Chlorella. J. gen. Physiol. 28, 103.

Nichols, B. W., Harris, R. V. \& James, A. T. (1965). The lipid metabolism of blue-green algae. Biochem. biophys. Res. Comm. 20, 256.

OGINSKy, E. L. (I957). Isolation and determination of arginine and citrulline. Meth. Enzymol. 3, 639.

Pearce, J. \& Carr, N. G. (1966). Enzymes of acetate metabolism in blue-green algae. J. gen. Microbiol. 45, i.

Ravel, J. M., Humphreys, J. S. \& Shive, W. (1965). Control of glutamine synthesis in Lactobacillus arabinosus. Arch. Biochem. Biophys. IrI, 720.

RichteR, G. (I96I). The lack of diphosphofructose aldolase in two photosynthetic organisms: Anacystis nidulans and Rhodopseudomonas spheroides. Biochim. biophys. Acta 48, 606.

Roberts, R. B., Cowie, D. B., Abelson, P. H., Bolton, E. T. \& Britten, R. J. (I955). Studies of biosynthesis in Escherichia coli. Publ. Carneg. Instn. No. 607. 
SADLER, W. R. \& STANIER, R. Y. (I960). The function of acetate in photosynthesis by green bacteria. Proc. natn. Acad. Sci. U.S.A. 46, 1328.

SpeCtOR, L. \& LipmanN, F. (I955). Carbamyl phosphate, the carbamyl donor in enzymatic citrulline synthesis. J. Am. chem. Soc. 77, 819.

Stadtman, E. R. (1957). Preparation and assay of acyl coenzyme A and other thiolesters; use of hydraxylamine. Meth. Enzymol. 3, $93 \mathrm{I}$.

StiLl, G. C. \& WANG, C. H. (1965). The role of the Krebs cycle reactions in the biosynthetic functions of Thiobacillus thioparus. Fedn Proc., Fedn Am. Socs exp. Biol. 24, 657.

STross, R. G. (1960). Growth response of Chlamydomonas and Haematococcus to the volatile fatty acids. Can. J. Microbiol. 6, 611.

TAYLOR, T. G. (1953). A modified procedure for the microestimation of citrate. Biochem. J. 54, 48.

Warburg, O. \& Christian, W. (1942). Isolierung und Kristallization des Gärungsferments Enolase. Biochem. Z. 310, 384.

WeBSter, G. C. \& FRENKEL, A. W. (1953). Some respiratory characteristics of the blue-green alga, Anabaena. Plant Physiol. 28, 63.

WIESSNER, W. (1964). Direct and indirect photometabolism of acetate in green algae. Plant Physiol. 39, XIV.

Willard, J. M., Schulman, M. \& GibBs, M. (1965). Aldolase in Anacystis nidulans and Rhodopseudomonas spheroides. Nature, Lond. 206, 195.

Yemm, E. W. \& Cocking, E. C. (1954). The determination of amino acids with ninhydrin. Analyst. 8o, 209. 